\title{
Multiple Correlation Analyses of Metabolic and Endocrine Profiles with Fertility in Primiparous and Multiparous Cows
}

\author{
D. C. Wathes, ${ }^{\star 1}$ N. Bourne, ${ }^{\star}$ Z. Cheng, ${ }^{\star}$ G. E. Mann,† V. J. Taylor, ${ }^{\star 2}$ and M. P. Coffey \\ ${ }^{*}$ Reproduction, Genes and Development Group, Royal Veterinary College, Hawkshead Lane, North Mymms, Hatfield, Herts AL9 7TA, UK \\ †Division of Animal Physiology, School of Biosciences, University of Nottingham, Sutton Bonington Campus, Loughborough, \\ Leics, LE12 5RD, UK \\ ¥SAC, Bush Estate, Penicuik, Midlothian, EH26 OPH, Scotland
}

\section{ABSTRACT}

Results from 4 studies were combined (representing a total of 500 lactations) to investigate the relationships between metabolic parameters and fertility in dairy cows. Information was collected on blood metabolic traits and body condition score at 1 to 2 wk prepartum and at 2, 4, and 7 wk postpartum. Fertility traits were days to commencement of luteal activity, days to first service, days to conception, and failure to conceive. Primiparous and multiparous cows were considered separately. Initial linear regression analyses were used to determine relationships among fertility, metabolic, and endocrine traits at each time point. All metabolic and endocrine traits significantly related to fertility were included in stepwise multiple regression analyses alone (model 1), including peak milk yield and interval to commencement of luteal activity (model 2 ), and with the further addition of dietary group (model 3). In multiparous cows, extended calving to conception intervals were associated prepartum with greater concentrations of leptin and lesser concentrations of nonesterified fatty acids and urea, and postpartum with reduced insulinlike growth factor-I at $2 \mathrm{wk}$, greater urea at $7 \mathrm{wk}$, and greater peak milk yield. In primiparous cows, extended calving to conception intervals were associated with more body condition and more urea prepartum, elevated urea postpartum, and more body condition loss by $7 \mathrm{wk}$. In conclusion, some metabolic measurements were associated with poorer fertility outcomes. Relationships between fertility and metabolic and endocrine traits varied both according to the lactation number of the cow and with the time relative to calving.

Key words: metabolic profile, fertility, dairy cow, parity

\footnotetext{
Received May 25, 2006.

Accepted October 19, 2006.

${ }^{1}$ Corresponding author: dcwathes@rvc.ac.uk

${ }^{2}$ Current address: Department of Biological Sciences, The Open University, Walton Hall, Milton Keynes, Bucks MK7 6AA, UK.
}

\section{INTRODUCTION}

Fertility in dairy cows has declined steadily over the past $40 \mathrm{yr}$ as milk yields have increased (Royal et al., 2000). At the start of lactation, DMI is insufficient to meet the demands of lactation, resulting in a period of negative energy balance (NEB) in the immediate postpartum period, which may last $20 \mathrm{wk}$ (Beever et al., 2001). Available evidence indicates that selection for increased milk yield has produced cows that are better able to mobilize body tissue reserves to support milk production, resulting in significant BCS loss (Pryce et al., 2001). The majority of UK dairy herd managers aim to start breeding cows from around $8 \mathrm{wk}$ after calving. At this time, many cows are still in NEB (Reist et al., 2003; Taylor et al., 2003). Milk progesterone profiles have shown that NEB is associated with a greater incidence of irregular estrous cycles that can delay the interval to first service. Whereas work in the UK in the 1970s reported that about 30\% of cows showed irregular cyclicity, more recent studies in the 1990s have reported greater incidences, in the range 45 to 55\% (Opsomer et al., 1998; Royal et al., 2000; Taylor et al., 2003). Evidence exists that a period of NEB can have long-term carryover effects on fertility, possibly though deleterious effects on developing follicles and their oocytes (Britt, 1994).

Parturition and lactogenesis are accompanied by many physiological changes that facilitate the maintenance of homeostasis (Bauman and Currie, 1980). When nutrients, in particular glucose, are in limited supply, NEFA are released from lipid stores and oxidized in the liver as an alternative energy source. Oxidation of NEFA results in the production of ketone bodies, and their concentration in blood is thus an index of fatty acid oxidation. Blood urea concentration in latepregnant and early-lactating ruminants is influenced by 1) the degree of protein catabolism that occurs, 2) the concentrations of RDP and RUP in the diet, and 3) the ratio of energy to protein in the diet (Bell, 1995; Moore and Varga, 1996). Circulating concentrations of many metabolic hormones also are altered. Interdependent changes occur in the growth hormone (GH)-insu- 
lin-IGF-I-glucose signaling pathway in early lactation (Lucy et al., 2001). Insulin concentrations tend to decrease in early lactation, particularly in higher yielding cows (Taylor et al., 2003). This is likely one of the factors associated with down-regulation of liver $\mathrm{GH}$ receptors, and hence a decrease in circulating IGF-I following calving (Butler et al., 2003). Plasma leptin concentrations in late pregnancy are strongly correlated with BCS (Ehrhardt et al., 2000), and they also decrease near parturition (Ingvartsen and Boisclair, 2001).

Many studies have related blood metabolite measurements in cattle to subsequent fertility, but no clear pattern has emerged (O'Callaghan et al., 2001; Westwood et al., 2002). There is evidence that the nadir in IGF-I measured shortly after calving is a useful index of energy balance status that affects the interval to the start of estrous cycles (Beam and Butler, 1999; Pushpakumara et al., 2003). Insulin has actions at all levels of the hypothalamic-pituitary-ovarian axis that likely influence fertility (Beam and Butler, 1999; Lucy et al., 2001). Leptin may affect reproduction through direct effects on the ovary or indirect effects on appetite (Blache et al., 2000a; Spicer, 2001). Many studies have reported significant effects of blood urea concentrations on fertility (Jordan and Swanson; 1979; Butler and Smith, 1989; Ferguson and Chalupa, 1989), but others have failed to find any (O'Callaghan et al., 2001).

Two possible reasons why previous investigations may not always have detected significant relationships between metabolic traits and fertility are that animal numbers were sometimes insufficient and cows may not have been sampled at the most relevant time point. To overcome such limitations, we combined the results from 4 studies and analyzed them by using a multiple correlation model to determine which metabolic variables were most influential in predicting fertility both before and after calving. Significant metabolic differences exist between cows calving for the first and subsequent times (Meikle et al., 2004; Wathes et al., 2006). At least $30 \%$ of cows in the herd are in their first lactation and such animals are commonly used for herd expansion programs. All the analyses were therefore performed separately for primiparous (PP) and multiparous (MP) cows. The study tested the hypothesis that the major changes in metabolic status of cows that occur near calving in association with NEB would be reflected in blood measurements and could be used to predict fertility in that lactation. Furthermore, these measures may, in the future, provide useful phenotypic variables to include in genetic selection programs.

\section{MATERIALS AND METHODS}

\section{Cows, Diets, and Sample Collection}

Data from 4 studies conducted between 1997 and 2003 to investigate the relationships between metabolic parameters and fertility in Holstein-Friesian dairy cows in the UK were combined, representing a total of 500 lactations (Table 1). Thirty-eight cows were used in 2 consecutive years and all others were included only once. Some groups of cows on the same farm were fed different diets (see Table 1). For subsequent analysis, these were considered as different dietary groups. All work was conducted under the Animals (Scientific Procedures) Act 1986 with local ethical approval. Each study included information on blood metabolic and endocrine traits, parity, diet, milk progesterone profile, and fertility. In each lactation, blood metabolites and hormones were measured at 1 to 2 wk before calving and at 2 to 3,4 to 5 , and 7 to 8 wk postpartum. Blood samples were collected from the coccygeal vein or artery into 9-mL heparinized Vacutainer tubes (BD Vacutainer, Plymouth, Devon, UK).

All cows were fed a TMR with new feed provided after the morning milking, and blood samples were collected approximately $2 \mathrm{~h}$ later. Samples were kept on ice, centrifuged shortly after collection at $1,600 \times g$ at $4^{\circ} \mathrm{C}$, and stored at $-20^{\circ} \mathrm{C}$. The blood metabolic hormones measured were IGF-I, insulin, and leptin. The blood metabolites measured were BHBA, NEFA, and urea. At each time point, BCS also was assessed by using a 0 to 5 scale (Webster, 1987) based on the amount of subcutaneous fat and muscle in the loin area around the lumbar vertebrae and in the area between the pelvis and tail head $(0=$ very poor, $1=$ poor, $2=$ moderate, $3=$ good, $4=$ fat, and $5=$ grossly fat). In most of the groups, parlor measurements of yield were automatically recorded at each milking for individual cows, although measurements from some farms were based on monthly milk recording visits (Table 1). These recordings were used to determine the peak milk yield (PMY) for each cow on the study.

Dietary group was included in the model to account for management differences among different groups of cows. Further dietary details are provided in a separate paper (Wathes et al., 2006). For feed analysis, samples of silage were collected weekly during the study period, stored frozen, and later pooled for analysis. Samples of all other individual feedstuffs used were collected and analyzed by ADAS Laboratories (Wolverhapton, UK). Based on these values, protein and energy density of the diets fed to different groups was calculated (Table 1). The ME values were in the range of 11.0 to $12.4 \mathrm{MJ} /$ $\mathrm{kg}$ of DM, and CP concentrations varied from 13.3 to $22.8 \%$. All cows were milked twice daily, with 2 exceptions in which cows were milked 3 times daily during the first 4 mo of lactation (Table 1).

All cows were inseminated by a trained technician following every observed estrus after a voluntary waiting period of about 7 to $8 \mathrm{wk}$. Inseminations were usu- 
Table 1. Summary information on dietary groups and milk yields for all cows included in the analysis

\begin{tabular}{|c|c|c|c|c|c|c|c|c|c|}
\hline \multirow[b]{2}{*}{ Item } & \multirow[b]{2}{*}{ Farm } & \multirow[b]{2}{*}{$\begin{array}{l}\text { Dietary } \\
\text { group }\end{array}$} & \multirow[b]{2}{*}{ Study } & \multirow[b]{2}{*}{ Year } & \multirow[b]{2}{*}{ No. } & \multirow[b]{2}{*}{$\begin{array}{l}\text { Milk yield, } \\
\text { kg/126 d }{ }^{1}\end{array}$} & \multicolumn{3}{|c|}{ Dietary measure } \\
\hline & & & & & & & $\begin{array}{l}\text { CP, } \\
\text { g/kg } \\
\text { of DM }\end{array}$ & $\begin{array}{l}\mathrm{ME}, \\
\mathrm{MJ} / \mathrm{kg} \\
\text { of DM }\end{array}$ & $\begin{array}{l}\text { Protein: } \\
\text { energy, g } \\
\text { of CP/MJ }\end{array}$ \\
\hline \multirow[t]{9}{*}{ Primiparous cows } & 1 & 1 & 3 & 1999-2000 & 11 & $3,000 \pm 108$ & 172 & 11.8 & 14.6 \\
\hline & 1 & 2 & 3 & 1999-2000 & 47 & $3,265 \pm 59$ & 187 & 12.2 & 15.3 \\
\hline & 1 & 3 & 3 & $1999-2000$ & 18 & $3,477 \pm 138$ & 173 & 12.3 & 14.1 \\
\hline & 2 & $4^{2}$ & 3 & $1999-2000$ & 38 & $3,621 \pm 89$ & 188 & 11.9 & 15.8 \\
\hline & 2 & 5 & 3 & 1999-2000 & 44 & $3,439 \pm 90$ & 228 & 11.9 & 19.2 \\
\hline & $3^{3}$ & 6 & 3 & $1999-2000$ & 3 & $3,756 \pm 250$ & 182 & 12.1 & 15.0 \\
\hline & $3^{3}$ & 7 & 3 & $1999-2000$ & 3 & $3,470 \pm 21$ & 182 & 12.4 & 14.7 \\
\hline & $4^{3}$ & 8 & 3 & $1999-2000$ & 16 & $3,867 \pm 108$ & 204 & 12.4 & 16.5 \\
\hline & $5^{3}$ & 9 & 3 & $1999-2000$ & 8 & $4,343 \pm 365$ & 138 & 11.0 & 12.6 \\
\hline Total & & & & & 188 & & & & \\
\hline \multirow[t]{12}{*}{ Multiparous cows } & 2 & 10 & 1 & 1997-1998 & 30 & $4,128 \pm 118$ & 198 & 12.2 & 16.2 \\
\hline & 2 & $11^{2}$ & 2 & 1998-1999 & 28 & $5,461 \pm 123$ & 178 & 12.0 & 14.8 \\
\hline & 2 & 12 & 2 & 1998-1999 & 20 & $4,053 \pm 140$ & 172 & 12.0 & 14.5 \\
\hline & 2 & 13 & 3 & 1999-2000 & 26 & $5,024 \pm 205$ & 188 & 11.9 & 15.8 \\
\hline & 2 & 14 & 3 & 1999-2000 & 15 & $5,489 \pm 198$ & 184 & 12.0 & 15.4 \\
\hline & 2 & 15 & 3 & 1999-2000 & 15 & $5,272 \pm 179$ & 189 & 12.0 & 15.8 \\
\hline & 2 & 16 & 4 & 2001-2002 & 49 & $4,947 \pm 86$ & 165 & 12.4 & 13.3 \\
\hline & $3^{3}$ & 6 & 3 & 1999-2000 & 25 & $5,212 \pm 118$ & 182 & 12.1 & 15.0 \\
\hline & $3^{3}$ & 7 & 3 & 1999-2000 & 18 & $4,965 \pm 198$ & 182 & 12.4 & 14.7 \\
\hline & $4^{3}$ & 8 & 3 & $1999-2000$ & 30 & $5,116 \pm 122$ & 204 & 12.4 & 16.5 \\
\hline & $5^{3}$ & 9 & 3 & 1999-2000 & 22 & $5,013 \pm 134$ & 138 & 11.0 & 12.6 \\
\hline & $6^{3}$ & 17 & 3 & $1999-2000$ & 34 & $3,904 \pm 108$ & 133 & 11.7 & 11.4 \\
\hline Total & & & & & 312 & & & & \\
\hline
\end{tabular}

${ }^{1}$ Milk yields are given for the first 126 DIM. Values are mean \pm SEM.

${ }^{2}$ Milked 3 times daily for the first 4 mo of lactation.

${ }^{3}$ Milk yields in these herds were estimated from monthly milk recording.

ally performed once daily, after the morning milking. Milk samples were collected twice weekly postpartum (Mondays and Thursdays, or Tuesdays and Fridays) from each cow from $10 \mathrm{~d}$ postpartum to determine the time of the first progesterone increase $(>3 \mathrm{ng} / \mathrm{mL})$ after calving and to date conception accurately (based on a persistently elevated milk progesterone reading for more than $25 \mathrm{~d}$ after insemination when progesterone level was baseline at AI). Pregnancies were later confirmed by palpation per rectum. Fertility traits measured were days to commencement of luteal activity (CLA, first progesterone increase $>3 \mathrm{ng} / \mathrm{mL}$; Bulman and Lamming, 1978), days to first service, and days to conception. Fertility measures were log transformed to produce a normal distribution.

\section{Blood and Milk Measurements}

The total IGF-I concentration in plasma was measured by RIA according to the method of Enright et al. (1989). Inter- and intraassay coefficients of variation were 11.2 and $6.7 \%$, respectively. Plasma insulin was measured by bovine ELISA kits (DRG Diagnostics, Immuno Diagnostic Systems Ltd., Tyne and Wear, UK). Assay sensitivity was $0.20 \mathrm{ng} / \mathrm{mL}$. Inter- and intraassay coefficients of variation were 8.9 and $9.4 \%$, respectively.
Leptin was measured by an RIA that used recombinant bovine leptin, as described and validated by Blache et al. (2000b). Inter- and intraassay coefficients of variation were 13.1 and $8.5 \%$, respectively, and sensitivity was $0.2 \mathrm{ng} / \mathrm{mL}$. Plasma concentrations of BHBA, NEFA, and urea were measured on an Operationally Enhanced Random Access analyzer (Bayer, Newbury, Berks, UK) using kinetic enzymatic kits (Randox Laboratories Ltd., Co. Antrim, UK; NEFA test kit, BHBA RANBUT D-3hydroxybutyrate test kit, urea test kit). The ranges were as follows: BHBA 0.1 to $1 \mathrm{mmol} / \mathrm{L}, \mathrm{NEFA} 0.1$ to $2 \mathrm{mmol} / \mathrm{L}$, and urea 0.1 to $7.5 \mathrm{mmol} / \mathrm{L}$. Progesterone was analyzed in whole milk samples by RIA using the method of Bulman and Lamming (1978). The detection limit was $2 \mathrm{ng} / \mathrm{mL}$ and inter- and intraassay coefficients of variation were 9.7 and $4.2 \%$, respectively.

\section{Statistical Analysis and Model Development}

Basic fertility data were initially compared by using 1-way ANOVA (SPSS version 12; SPSS, Chicago, IL). For subsequent modeling, PP (lactation number $=1$ ) and MP cows (lactation number $>1$, range 2 to 8 ) were considered separately. Using the ASREML software package (residual maximum likelihood; Gilmour et al., 2003), coefficients of polynomial equations were calcu- 
Table 2. A comparison of fertility traits in primiparous and multiparous cows ${ }^{1}$

\begin{tabular}{lcccc}
\hline Fertility trait & No. & Primiparous & No. & Multiparous \\
\hline Days to commencement of luteal activity & 188 & $28 \pm 1.4$ & $305^{2}$ & $27 \pm 1.0$ \\
No. studied but not inseminated & 8 & $4 \%$ & 9 & $3 \%$ \\
Days to first service & 180 & $78 \pm 2.4^{\mathrm{a}}$ & 296 & $73 \pm 1.1^{\mathrm{b}}$ \\
No. conceiving to first service & 65 & $36 \%$ & 137 & $46 \%$ \\
Days to conception for cows that conceived & 150 & $94 \pm 5.3$ & 263 & $96 \pm 2.3$ \\
Services/conception for cows that conceived & 150 & $1.6 \pm 0.09$ & 263 & $1.9 \pm 0.08$ \\
No. inseminated that failed to conceive (FTC) & 30 & $17 \%$ & 33 & $11 \%$ \\
No. services given to FTC cows & 30 & $3.6 \pm 0.32$ & 33 & $2.6 \pm 0.30$ \\
Range of services given to FTC cows & 30 & $1-6$ & 33 & $1-7$ \\
DIM until final service for FTC cows & 30 & $187 \pm 12.4$ & 33 & $135 \pm 25.0$ \\
Range of DIM until final service for FTC cows & 30 & $55-274$ & 33 & $61-248$ \\
\hline a,b Means bearing different superscript letters differ $(P<0.05)$. & & \\
${ }^{1}$ Values are mean \pm SEM. & & &
\end{tabular}

lated for each trait measured between $1 \mathrm{wk}$ before calving and 7 wk postpartum, with dietary group included as a fixed factor in the model. Because there were repeated observations for each cow, cow was included in all models as a random effect and cow deviations from the overall curve were allowed to vary linearly. Figures for each trait were drawn for each equation, using the optimal statistical model that best fitted the data and that was parsimonious. All equations were then used to predict missing values in the original data set. The new data set allowed changes to be determined for all metabolites between each sample time point. The completed data set was used in a multiple correlation model to determine the relationships between each of the metabolic traits measured and fertility. Initial linear regression analyses were performed using data from each of the 4 collection time points ( $1 \mathrm{wk}$ before calving and 2 , 4 , and $7 \mathrm{wk}$ postpartum). The metabolic data, including BCS, were compared with the 3 fertility traits using 2 analysis programs: 1) univariate analysis with dietary group (see Table 1) included as a fixed effect using ASREML, and 2) single-variable regression using SPSS version 12 (SPSS, Chicago, IL). All metabolic and endocrine traits that showed a significant relationship with a particular fertility measure at each time point were then included in a stepwise multiple regression analysis in ASREML. Three models were tested as follows. 1) The initial model included only metabolic and BCS measures as factors. Factors were added or removed to obtain the best-fit model showing the minimum residual variation. 2) The second model also included PMY and C-LA in the analyses of intervals to first service and to conception. Peak milk yield was included as a factor only in the postcalving time points. 3) The final model also included dietary group as a fixed effect.

This approach enabled us to examine the effects of metabolic factors on fertility and then to test whether they remained significant when yield and nutritional group also were included in the model. Cows that failed to conceive were, by definition, excluded from the analysis of factors affecting the interval to conception.

Finally, the results indicated that BCS and urea might be useful traits to measure as predictors of fertility. An analysis was therefore undertaken in which MP and PP cows were categorized into those having high, medium, and low prepartum values and at $7 \mathrm{wk}$ postpartum as follows: $\mathrm{BCS}<2,2$ to 2.9 , and $\geq 3$; urea $<4.5$, 4.5 to 7.5 , and $>7.5 \mathrm{mmol} / \mathrm{L}$. Fertility traits for cows in each category were then compared using 1-way ANOVA.

\section{RESULTS}

\section{Basic Metabolic, Endocrine, and Fertility Traits}

A summary of the fertility measures for the PP and MP cows is given in Table 2. Values were similar for the 2 age groups, with the exception that there was a slightly greater interval to first service in PP cows. Cows were included in the study when the milk sample was collected for progesterone analysis at $\mathrm{d} 10$ postpartum. At this point, it was the intention of the herd managers to inseminate all cows to achieve a pregnancy. However, a few cows (3.4\%) were never inseminated because of illness or accident. A further $17 \%$ of PP cows and $11 \%$ of MP cows failed to conceive. These cows received between 1 and 7 inseminations before a decision was made to discontinue breeding. Reasons behind such decisions were varied and included consideration of general health status (lameness, mastitis, etc.), DIM, and age. For PP cows, $36 \%$ overall conceived to first service. The greatest interval to conception was $281 \mathrm{~d}$, with this cow having an interval of $215 \mathrm{~d}$ between the first and last insemination. For MP cows, 46\% conceived to first service. The greatest interval to concep- 
Table 3. Effect of lactation number on commencement of luteal activity (C-LA)

\begin{tabular}{|c|c|c|c|c|}
\hline $\begin{array}{l}\text { Lactation } \\
\text { no. }\end{array}$ & No. & Days to C-LA $^{1}$ & $\begin{array}{l}\text { Maximum } \\
\text { days to C-LA }\end{array}$ & $\begin{array}{c}\text { No. of cows } \\
\text { having C-LA } \geq 45 \mathrm{~d} \\
\text { (delayed } \\
\text { ovulation, } \%)^{2}\end{array}$ \\
\hline 1 & 188 & $28.5 \pm 1.4^{\mathrm{a}}$ & 111 & 39 (20.7) \\
\hline 2 & 128 & $23.6 \pm 1.1^{\mathrm{b}}$ & 82 & $10(7.8)$ \\
\hline 3 & 67 & $28.2 \pm 2.1$ & 97 & $8(11.9)$ \\
\hline 4 & 41 & $26.7 \pm 2.4$ & 76 & $4(9.7)$ \\
\hline 5 & 45 & $25.7 \pm 2.4$ & 99 & $3(6.7)$ \\
\hline$\geq 6$ & 24 & $26.0 \pm 2.6$ & 49 & 4 (16.7) \\
\hline Total >1 & 305 & & & 29 (9.5) \\
\hline
\end{tabular}

tion was $234 \mathrm{~d}$ and the greatest interval from first to last service was $163 \mathrm{~d}$.

A more detailed analysis of the effect of lactation number on C-LA is given in Table 3. This includes information on the proportion of cows in each age group requiring more than $45 \mathrm{~d}$ to resume cyclicity. This condition has been termed "delayed ovulation." The mean interval to C-LA generally ranged between 26 and 28 $\mathrm{d}$ but was slightly less $(P=0.002)$ in second-lactation cows $(23.6 \mathrm{~d})$. Whereas the majority of cows had resumed cyclicity by d 45 , a few cows in each age group had excessively delayed intervals. Incidence of delayed ovulation was greatest in first-lactation cows (20.7\%), decreased $(P=0.001)$ for cows in later lactations ( 2 to 5 ; 8.9\%), and then increased $(P=0.001)$ again in older cows (lactations 6 and 7, 16.7\%).

A detailed analysis of the metabolic and endocrine profiles of cows included in the study is presented in a separate paper (Wathes et al., 2006). Summary figures of the predicted least squares mean phenotypic values for each metabolic and endocrine trait during the 8-wk period from $1 \mathrm{wk}$ before calving until $7 \mathrm{wk}$ postpartum are shown in Figure 1.

\section{MP Cows}

Interval to C-LA. Results of the 3 models are summarized in Table 4. In model 1, the principal trait influencing C-LA was the concentration of leptin both before and after calving ( $2 \mathrm{wk}$ ). The MP cows having greater concentrations of leptin after calving took longer $(P<$ $0.001)$ to resume cyclicity. Before calving there was a minor additional adverse effect of greater BHBA concentration, which became significant at 2 wk postpartum $(P<0.05)$. By 4 wk the majority of cows had already resumed cyclicity (Table 3$)$. The significant $(P<0.05)$ effect of BCS measured at $7 \mathrm{wk}$ was therefore symptomatic of cows with a delayed start to cyclicity. Mean BCS for cows with a delayed ovulation profile at $7 \mathrm{wk}$ were lower $(P<0.05)$ than those for the remaining cows that had resumed cyclicity by $d 45(1.5 \pm 0.15$ vs. $1.9 \pm 0.04$, respectively). Concentrations of NEFA also were greater $(P<0.01)$ at 4 wk in cows having delayed ovulation $(0.51 \pm 0.08$ vs. $0.34 \pm 0.02 \mathrm{mmol} / \mathrm{L})$.

The PMY was included as a factor only in models 2 and 3 in the postcalving time points. Its influence was significant $(P<0.01)$ at 2 wk only. Because 2 wk is before PMY occurs, cows that are mobilizing more tissue to support lactation in the early postpartum period were subsequently more likely to have a longer C-LA. In model 3 , an effect of the dietary group was detected at the 2 later time points ( $4 \mathrm{wk}, P<0.01$, and $7 \mathrm{wk}, P<$ 0.001 ), which made the model slightly more parsimonious because, in each case, a reduction in the size of the error variance component occurred, compared with model 2 values. When dietary group was included at 4 and $7 \mathrm{wk}$, other traits became nonsignificant. This indicated the importance of lactational diet, or other management factors, in influencing the interval to C-LA.

Interval to First Service. An elevated prepartum leptin concentration in MP cows also was associated with a prolonged $(P<0.001)$ interval to first service (Table 5, model 1). At 2 and $4 \mathrm{wk}$, the main significant trait was the IGF-I concentration, with the model improved by the additional inclusion of BCS. In both cases, the relationship was negative, so cows having a lower $(P<0.01)$ IGF-I concentration and BCS at this stage took longer to reach first service. By $7 \mathrm{wk}$ (end of the voluntary waiting period), the effect of BCS had become significant $(P<0.05)$, whereas that of the IGF-I concentration was then just below significance. However, 
MP cows
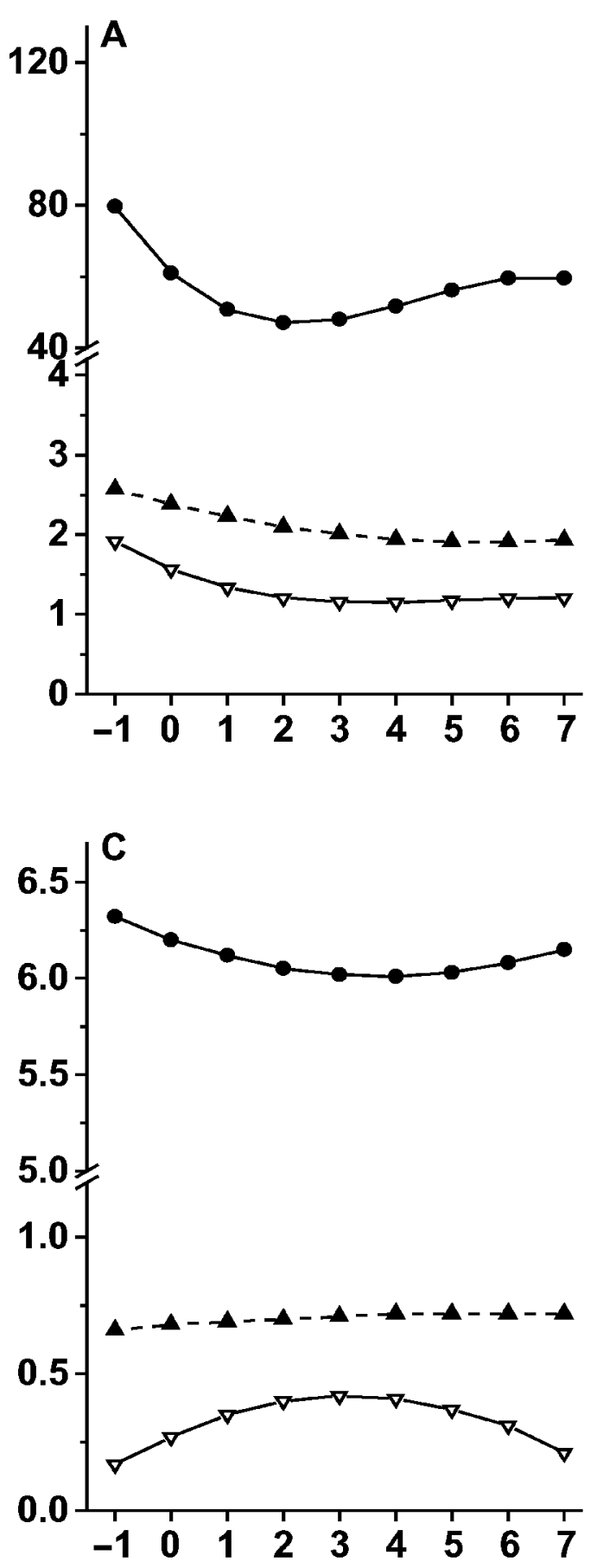

PP cows
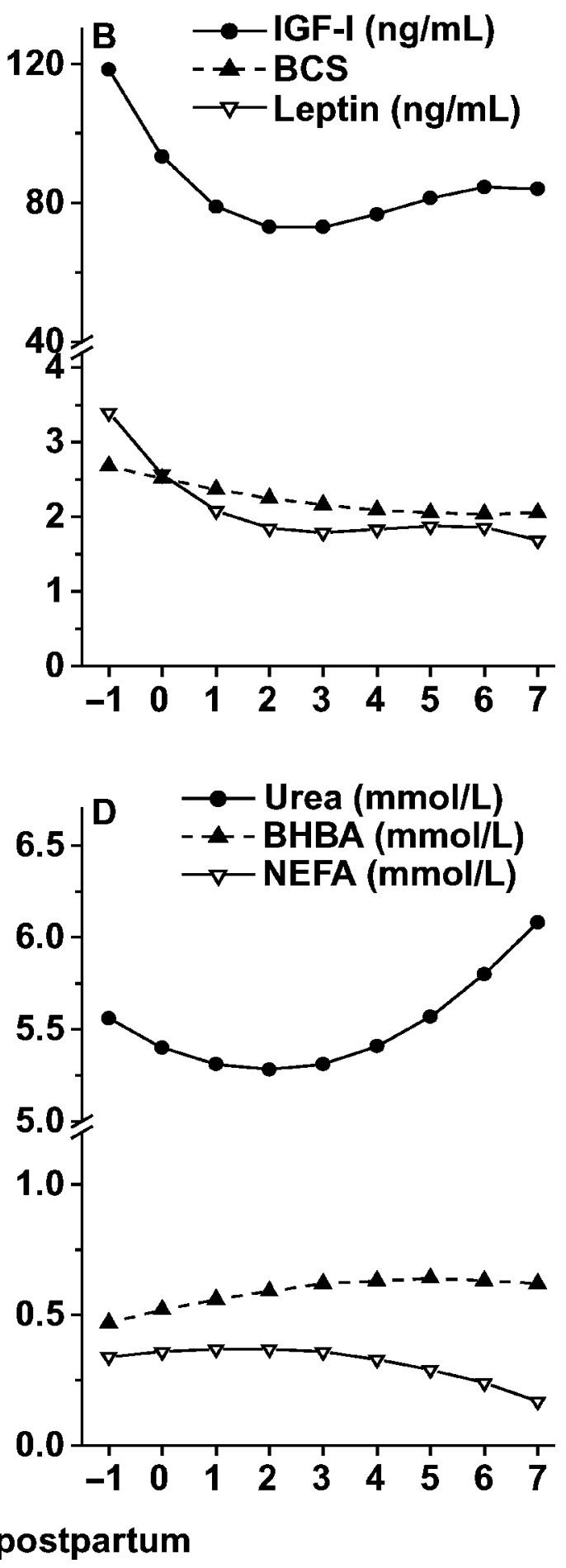

Figure 1. Least squares means for phenotypic values over time for the metabolic hormones and metabolites measured in cows included in this study as follows: IGF-I, BCS, and leptin in (A) multiparous (MP) cows and (B) primiparous (PP) cows; and urea, BHBA, and NEFA in (C) MP cows and (D) PP cows. A detailed analysis of the data is given in Wathes et al. (2006). Insulin has been omitted for clarity because its inclusion did not improve the fit of any of the models related to interval to conception. 
Table 4. Traits influencing the time to commencement of luteal activity (C-LA) in multiparous cows at 4 different time points in relation to calving

\begin{tabular}{|c|c|c|c|c|c|c|c|c|c|}
\hline \multirow[b]{2}{*}{$\begin{array}{l}\text { Time } \\
\text { point }\end{array}$} & \multicolumn{3}{|c|}{$\begin{array}{c}\text { Model } 1 \\
\text { Metabolites and hormones }\end{array}$} & \multicolumn{3}{|c|}{$\begin{array}{c}\text { Model } 2 \\
\text { Peak milk yield (PMY) }\end{array}$} & \multicolumn{3}{|c|}{$\begin{array}{c}\text { Model } 3 \\
\text { PMY and dietary group }\end{array}$} \\
\hline & $\begin{array}{l}\text { Factors } \\
\text { fitted }\end{array}$ & $t^{1}$ & $\begin{array}{l}\text { Regression } \\
\text { coefficient }\end{array}$ & $\begin{array}{l}\text { Factors } \\
\text { fitted }\end{array}$ & $t$ & $\begin{array}{l}\text { Regression } \\
\text { coefficient }\end{array}$ & $\begin{array}{l}\text { Factors } \\
\text { fitted }\end{array}$ & $t$ or $F^{1}$ & $\begin{array}{l}\text { Regression } \\
\text { coefficient }\end{array}$ \\
\hline \multirow[t]{4}{*}{$-1 \mathrm{wk}$} & Leptin & $2.9^{* *}$ & 0.0620 & & & & Leptin & 0.56 & 0.0195 \\
\hline & BHBA & 0.089 & 0.0873 & & & & BHBA & 1.38 & 0.0170 \\
\hline & T. & & & & & & Group & 0.89 & \\
\hline & $V_{\text {ariance }}$ & & 0.0505 & & & & Variance & & 0.0510 \\
\hline \multirow[t]{5}{*}{$2 \mathrm{wk}$} & Leptin & $3.02^{* * *}$ & 0.0453 & Leptin & $3.16^{* *}$ & 0.0963 & Leptin & 1.23 & 0.0256 \\
\hline & BHBA & $2.38^{*}$ & 0.1571 & BHBA & $2.41^{*}$ & 0.0156 & BHBA & 1.47 & 0.1163 \\
\hline & & & & PMY & $2.67^{* *}$ & 0.0026 & PMY & $2.04 *$ & 0.0054 \\
\hline & & & & & & & Group & 1.50 & \\
\hline & Variance & & 0.0498 & Variance & & 0.0477 & Variance & & 0.0464 \\
\hline \multirow[t]{5}{*}{$4 \mathrm{wk}$} & NEFA & 1.94 & 0.1092 & NEFA & 1.75 & 0.0998 & NEFA & 1.73 & 0.1581 \\
\hline & $\mathrm{BCS}$ & 1.72 & -0.0303 & $\mathrm{BCS}$ & 1.26 & -0.0405 & $\mathrm{BCS}$ & 1.95 & -0.0662 \\
\hline & & & & PMY & 1.06 & 0.0010 & PMY & 1.79 & 0.0038 \\
\hline & & & & & & & Group & $3.44 * * *$ & \\
\hline & Variance & & 0.0407 & Variance & & 0.0407 & Variance & & 0.0360 \\
\hline \multirow{3}{*}{$7 \mathrm{wk}$} & BCS & $2.81^{*}$ & -0.0702 & BCS & $2.45^{*}$ & 0.0646 & BCS & 1.72 & 0.0552 \\
\hline & & & & PMY & 0.69 & 0.0006 & $\begin{array}{l}\text { PMY } \\
\text { Group }\end{array}$ & $\begin{array}{l}1.89 \\
2.69 * *\end{array}$ & 0.0039 \\
\hline & Variance & & 0.0309 & Variance & & 0.0308 & Variance & & 0.0289 \\
\hline
\end{tabular}

${ }^{1}$ For $t$ and $F$ values, $* P<0.05, * * P<0.01, * * * P<0.001$

${ }^{2}$ Variance is the error variance component.

Table 5. Traits influencing the interval to first service in multiparous cows at 4 different time points in relation to calving

\begin{tabular}{|c|c|c|c|c|c|c|c|c|c|}
\hline \multirow[b]{2}{*}{$\begin{array}{l}\text { Time } \\
\text { point }\end{array}$} & \multicolumn{3}{|c|}{$\begin{array}{c}\text { Model } 1 \\
\text { Metabolites and hormones }\end{array}$} & \multicolumn{3}{|c|}{$\begin{array}{c}\text { Model } 2 \\
\text { C-LA and PMY }\end{array}$} & \multicolumn{3}{|c|}{$\begin{array}{c}\text { Model } 3 \\
\text { PMY, C-LA, and dietary group }\end{array}$} \\
\hline & $\begin{array}{l}\text { Factors } \\
\text { fitted }\end{array}$ & $t^{2}$ & $\begin{array}{l}\text { Regression } \\
\text { coefficient }\end{array}$ & $\begin{array}{l}\text { Factors } \\
\text { fitted }\end{array}$ & $t$ & $\begin{array}{l}\text { Regression } \\
\text { coefficient }\end{array}$ & $\begin{array}{l}\text { Factors } \\
\text { fitted }\end{array}$ & $t$ or $F^{2}$ & $\begin{array}{l}\text { Regression } \\
\text { coefficient }\end{array}$ \\
\hline \multirow[t]{2}{*}{$-1 \mathrm{wk}$} & Leptin & $3.27 * *$ & 0.0382 & & & & Leptin & 1.29 & 0.0217 \\
\hline & Variance $^{3}$ & & 0.0148 & & & & $\begin{array}{l}\text { Group } \\
\text { Variance }\end{array}$ & $3.11^{* *}$ & 0.0121 \\
\hline \multirow[t]{5}{*}{$2 \mathrm{wk}$} & IGF-I & $3.74 * * *$ & -0.0018 & IGF-I & $2.78 * *$ & -0.0013 & IGF-I & 1.42 & -0.0006 \\
\hline & BCS & 1.02 & -0.0020 & BCS & 1.84 & -0.0354 & BCS & $2.43^{*}$ & -0.0056 \\
\hline & & & & PMY & $3.77 * * *$ & 0.0060 & PMY & 0.43 & -0.0009 \\
\hline & & & & C-LA & 0.65 & 0.0375 & $\begin{array}{l}\text { C-LA } \\
\text { Group }\end{array}$ & $\begin{array}{l}0.63 \\
5.59 * * *\end{array}$ & -0.0342 \\
\hline & Variance & & 0.0215 & Variance & & 0.0195 & Variance & & 0.0155 \\
\hline \multirow[t]{5}{*}{$4 \mathrm{wk}$} & IGF-I & $2.92 * *$ & -0.0016 & IGF-I & $2.28 *$ & 0.0012 & IGF-I & 1.24 & -0.0006 \\
\hline & BCS & 1.76 & -0.0472 & BCS & 1.91 & -0.0513 & BCS & $2.43^{*}$ & -0.0614 \\
\hline & & & & PMY & $2.72^{* *}$ & 0.0036 & PMY & 0.79 & -0.0012 \\
\hline & & & & C-LA & 0.55 & 0.0342 & $\begin{array}{l}\text { C-LA } \\
\text { Group }\end{array}$ & $\begin{array}{l}1.04 \\
6.72 * * * *\end{array}$ & -0.0600 \\
\hline & Variance & & 0.0215 & Variance & & 0.0205 & Variance & & 0.0155 \\
\hline \multirow[t]{6}{*}{$7 \mathrm{wk}$} & $\mathrm{BCS}$ & $2.32 *$ & -0.0604 & $\mathrm{BCS}$ & $2.18^{*}$ & -0.0584 & BCS & $3.79 * * *$ & -0.0923 \\
\hline & Urea & $2.22 *$ & 0.0170 & Urea & 1.73 & 0.0139 & Urea & 1.26 & -0.0135 \\
\hline & IGF-I & 1.73 & -0.0611 & IGF-I & 1.41 & -0.0009 & IGF-I & 0.07 & -0.00004 \\
\hline & & & & PMY & 1.43 & 0.0021 & PMY & 1.52 & -0.0023 \\
\hline & & & & C-LA & 0.39 & 0.0299 & $\begin{array}{l}\text { C-LA } \\
\text { Group }\end{array}$ & $\begin{array}{l}1.32 \\
718 * * *\end{array}$ & -0.0938 \\
\hline & Variance & & 0.0213 & Variance & & 0.0212 & Variance & & 0.0151 \\
\hline
\end{tabular}

${ }^{1} \mathrm{C}-\mathrm{LA}=$ commencement of luteal activity; $\mathrm{PMY}=$ peak milk yield.

${ }^{2}$ For $t$ and $F$ values, $* P<0.05, * * P<0.01, * * * P<0.001$

${ }^{3}$ Variance is the error variance component. 
Table 6. Factors influencing interval to conception in multiparous cows at 4 different time points in relation to calving

\begin{tabular}{|c|c|c|c|c|c|c|c|c|c|}
\hline \multirow[b]{2}{*}{$\begin{array}{l}\text { Time } \\
\text { point }\end{array}$} & \multicolumn{3}{|c|}{$\begin{array}{c}\text { Model } 1 \\
\text { Metabolites and hormones }\end{array}$} & \multicolumn{3}{|c|}{$\begin{array}{c}\text { Model } 2 \\
\text { C-LA and PMY }{ }^{1}\end{array}$} & \multicolumn{3}{|c|}{$\begin{array}{c}\text { Model } 3 \\
\text { PMY, C-LA, and dietary grour }\end{array}$} \\
\hline & $\begin{array}{l}\text { Factors } \\
\text { fitted }\end{array}$ & $t^{2}$ & $\begin{array}{c}\text { Regression } \\
\text { coefficient }\end{array}$ & $\begin{array}{l}\text { Factors } \\
\text { fitted }\end{array}$ & $t$ & $\begin{array}{l}\text { Regression } \\
\text { coefficient }\end{array}$ & $\begin{array}{l}\text { Factors } \\
\text { fitted }\end{array}$ & $t$ or $F^{2}$ & $\begin{array}{l}\text { Regression } \\
\text { coefficient }\end{array}$ \\
\hline \multirow[t]{5}{*}{$-1 \mathrm{wk}$} & Leptin & $3.93 * * *$ & 0.0687 & & & & Leptin & $2.45^{*}$ & 0.0650 \\
\hline & NEFA & $3.28 * *$ & -0.2375 & & & & NEFA & $2.66^{* *}$ & -0.3691 \\
\hline & Urea & $2.12 *$ & -0.0256 & & & & Urea & 1.76 & -0.0269 \\
\hline & & & & & & & Group & 0.84 & \\
\hline & Variance $^{3}$ & & 0.0240 & & & & Variance & & 0.0245 \\
\hline \multirow[t]{5}{*}{$2 \mathrm{wk}$} & IGF-I & $2.71^{* *}$ & -0.0017 & IGF-I & 1.72 & -0.0010 & IGF-I & 0.53 & -0.0003 \\
\hline & BCS & 0.60 & -0.0153 & $\mathrm{BCS}$ & 1.65 & -0.0396 & $\mathrm{BCS}$ & 1.82 & -0.0597 \\
\hline & & & & PMY & $4.15^{* * *}$ & 0.0085 & PMY & 0.67 & 0.0019 \\
\hline & & & & C-LA & 1.30 & 0.0961 & C-LA & 0.95 & 0.0732 \\
\hline & Variance & & 0.0341 & Variance & & 0.0294 & Variance & & 0.0279 \\
\hline \multirow[t]{7}{*}{$4 \mathrm{wk}$} & Urea & $3.03^{* *}$ & 0.0271 & Urea & 1.35 & 0.0181 & Urea & 0.47 & 0.0043 \\
\hline & IGF-I & $2.22 *$ & -0.0016 & IGF-I & $1.96^{*}$ & -0.0010 & IGF-I & 0.35 & -0.0004 \\
\hline & $\mathrm{BCS}$ & 0.73 & -0.0261 & BCS & 0.86 & -0.0314 & $\mathrm{BCS}$ & 1.65 & -0.0628 \\
\hline & & & & PMY & 1.12 & 0.0882 & PMY & 0.71 & 0.0010 \\
\hline & & & & C-LA & $2.46^{*}$ & 0.0060 & C-LA & 0.31 & 0.0600 \\
\hline & & & & & & & Group & 1.71 & \\
\hline & Variance & & 0.0335 & Variance & & 0.0315 & Variance & & 0.0302 \\
\hline \multirow[t]{5}{*}{$7 \mathrm{wk}$} & Urea & $3.15^{* *}$ & 0.0315 & Urea & $2.16^{*}$ & 0.0224 & Urea & 0.50 & -0.0079 \\
\hline & BCS & $2.54^{*}$ & -0.0805 & BCS & $2.45^{*}$ & -0.0797 & BCS & $2.95^{* *}$ & -0.1017 \\
\hline & & & & PMY & $2.65^{* *}$ & 0.0063 & PMY & 0.23 & -0.0008 \\
\hline & & & & C-LA & 0.35 & -0.0328 & C-LA & 0.45 & -0.0464 \\
\hline & Variance & & 0.0319 & Variance & & 0.0306 & $\begin{array}{l}\text { Group } \\
\text { Variance }\end{array}$ & 1.75 & 0.0290 \\
\hline
\end{tabular}

${ }^{1} \mathrm{C}-\mathrm{LA}=$ commencement of luteal activity; PMY = peak milk yield.

${ }^{2}$ For $t$ and $F$ values, $* P<0.05, * * P<0.01, * * * P<0.001$.

${ }^{3}$ Variance is the error variance component

there was an additional positive $(P<0.05)$ relationship to the urea concentration at this time point.

Inclusion of PMY in model 2 was significant $(P<0.01)$ at both 2 and $4 \mathrm{wk}$, but no longer had a significant impact at the end of the voluntary waiting period. Inclusion of C-LA in model 2 did not approach significance at any time point. Inclusion of dietary group in model 3 was significant $(P<0.01)$ at all time points, suggesting that management decisions, diet, or both were influential. Including dietary group also increased the significance of BCS $(P<0.05)$ as an influencing factor in the postpartum period but removed the significance of IGFI and PMY, although both improved the fit of the model.

Interval to Conception. Factors affecting the interval to conception were very similar to those influencing the interval to first service (Table 6; model 1). Prepartum effects of NEFA $(P<0.01)$ and urea $(P<0.05)$ were also both significant, but in these cases the relationships were negative (i.e., cows calving having lesser NEFA and urea values took longer to conceive). Postcalving, the significant factors were again IGF-I, BCS, and urea, and again, a shift occurred in their relative importance, from IGF-I having a strong negative rela- tionship at 2 wk $(P<0.01)$ to $\mathrm{BCS}(P<0.05$, negative $)$ and urea $(P<0.01$, positive $)$ proving most influential at the end of the voluntary waiting period.

In model 2, inclusion of PMY, but not C-LA, was significant at $2(P<0.001)$ and $7(P<0.01)$ wk, whereas at $4 \mathrm{wk}$, inclusion of C-LA, but not PMY, in the model was significant $(P<0.05)$. Inclusion of dietary group in model 3 was not significant at any point and made little improvement to the overall fit of the model, as shown by a comparison of the error variance components with those from model 2 . This reduction in variance, coupled with the fact that the model developed prepartum was more parsimonious than that at any time after calving, emphasizes the importance of the precalving metabolic status on the subsequent ability of the cow to conceive.

Table 7 provides mean C-LA and PMY values subdivided according to those cows conceiving at $<80,80$ to 150 , or $>150$ d postpartum. Both C-LA and PMY generally increased as the calving to conception interval increased. Cows with the longest calving to conception intervals of $>150 \mathrm{~d}$ resumed cycles, on average, $18 \mathrm{~d}$ later $(P<0.01)$ and produced $14 \mathrm{~kg} / \mathrm{d}$ more $(P<0.01)$ milk than those conceiving $<80 \mathrm{~d}$ postpartum (Table 7 ). 
Table 7. Relationships between commencement of luteal activity (C-LA) and peak milk yield (PMY) with conception data in multiparous and primiparous cows ${ }^{1}$

\begin{tabular}{|c|c|c|c|c|c|c|}
\hline \multirow{2}{*}{$\begin{array}{l}\text { Interval from } \\
\text { calving to } \\
\text { conception, d }\end{array}$} & \multicolumn{3}{|c|}{ Multiparous cows } & \multicolumn{3}{|c|}{ Primiparous cows } \\
\hline & No. & C-LA, d & PMY, kg/d & No. & C-LA, d & $\mathrm{PMY}, \mathrm{kg} / \mathrm{d}$ \\
\hline$<80$ & 67 & $24.1 \pm 1.1^{\mathrm{c}}$ & $34.9 \pm 0.8^{\mathrm{c}}$ & 36 & $24.8 \pm 2.5^{\mathrm{a}}$ & $30.3 \pm 0.9$ \\
\hline 80 to 150 & 81 & $28.1 \pm 1.7^{\mathrm{d}}$ & $43.3 \pm 0.9^{\mathrm{d}}$ & 80 & $28.7 \pm 1.9^{\mathrm{ab}}$ & $31.7 \pm 0.5$ \\
\hline$>150$ & 27 & $41.7 \pm 8.0^{\mathrm{d}}$ & $48.5 \pm 1.1^{\mathrm{e}}$ & 32 & $34.5 \pm 4.1^{\mathrm{b}}$ & $32.6 \pm 0.8$ \\
\hline
\end{tabular}

${ }^{\mathrm{a}, \mathrm{b}}$ Means bearing different superscript letters within columns differ $(P<0.05)$.

${ }^{c-e}$ Means bearing different superscript letters within columns differ $(P<0.01)$.

${ }^{1}$ Values are mean $\pm \mathrm{SEM}$.

\section{PP Cows}

Interval to $\boldsymbol{C}$-LA. The results are summarized in Table 8. In contrast to MP cows, the prepartum leptin concentration was not important, but in model 1 there was a negative relationship with the BHBA concentration (i.e., a lesser BHBA value at this time led to a prolonged $(P<0.01)$ C-LA interval. By 2 wk postpartum, the situation had reversed, with a significant $(P<0.001)$ positive relationship to BHBA. A negative influence of urea occurred at both these time points and remained significant $(P<0.05)$ at $4 \mathrm{wk}$. By $7 \mathrm{wk}$ (when the majority of animals were already cyclic), there was a significant positive influence of NEFA $(P<0.05)$ and a nega- tive effect of BCS $(P<0.05)$. Inclusion of insulin and BCS at $4 \mathrm{wk}$ and IGF-I at $7 \mathrm{wk}$ improved the fit of the model.

As with the MP cows, inclusion of PMY in model 2 was significant $(P<0.05)$ only at the first time point after calving. In model 3 , no significant effect of nutritional group was detected at any time, but it caused a slight improvement in the fit of the model.

Interval to First Service. In model 1, a positive effect was detected for both BCS $(P<0.001)$ and urea $(P<0.001)$ on the interval to first service, both prepartum and 2 wk postpartum (i.e., PP cows that calved with greater BCS and urea concentrations had prolonged

Table 8. Traits affecting time to commencement of luteal activity in primiparous cows at 4 different time points in relation to calving

\begin{tabular}{|c|c|c|c|c|c|c|c|c|c|}
\hline \multirow[b]{2}{*}{$\begin{array}{l}\text { Time } \\
\text { point }\end{array}$} & \multicolumn{3}{|c|}{$\begin{array}{l}\text { Model } 1 \\
\text { Metabolites and hormones }\end{array}$} & \multicolumn{3}{|c|}{$\begin{array}{c}\text { Model } 2 \\
\text { Peak milk yield (PMY) }\end{array}$} & \multicolumn{3}{|c|}{$\begin{array}{c}\text { Model } 3 \\
\text { PMY and dietary group }\end{array}$} \\
\hline & $\begin{array}{l}\text { Factors } \\
\text { fitted }\end{array}$ & $t^{1}$ & $\begin{array}{c}\text { Regression } \\
\text { coefficient }\end{array}$ & $\begin{array}{l}\text { Factors } \\
\text { fitted }\end{array}$ & $t$ & $\begin{array}{c}\text { Regression } \\
\text { coefficient }\end{array}$ & $\begin{array}{l}\text { Factors } \\
\text { fitted }\end{array}$ & $t$ or $F^{1}$ & $\begin{array}{l}\text { Regression } \\
\text { coefficient }\end{array}$ \\
\hline \multirow[t]{4}{*}{$-1 \mathrm{wk}$} & BHBA & $2.90 * *$ & -0.0309 & & & & BHBA & 0.7 & -0.0830 \\
\hline & Urea & 1.44 & -0.1421 & & & & Urea & $2.26^{*}$ & -0.0363 \\
\hline & & & & & & & Group & 1.63 & \\
\hline & varias & & 0.0587 & & & & & & 0.0569 \\
\hline \multirow[t]{5}{*}{$2 \mathrm{wk}$} & BHBA & $3.32^{* * *}$ & 0.1015 & BHB & $2.95^{* *}$ & 0.0902 & BHBA & $2.27^{*}$ & 0.0 \\
\hline & Urea & $2.47^{*}$ & -0.0272 & Urea & $2.81^{* *}$ & -0.0312 & Urea & 0.05 & 0.00002 \\
\hline & & & & PMY & $2.44^{*}$ & 0.0086 & PMY & $2.77^{* *}$ & 0.0103 \\
\hline & & & & & & & Group & 1.57 & \\
\hline & Variance & & 0.0540 & Variance & & 0.0527 & Variance & & 0.0512 \\
\hline \multirow[t]{5}{*}{$4 \mathrm{wk}$} & Urea & $2.46^{*}$ & -0.0323 & Ure & $2.61^{* *}$ & -0.0345 & Ure & 1.77 & 68 \\
\hline & Insulin & 1.73 & -0.1869 & Insulin & 1.62 & -0.1746 & Insulin & $1 . \varepsilon$ & -0.2138 \\
\hline & BCS & 1.37 & -0.0532 & BCS & 1.40 & -0.0538 & BCS & 1.42 & -0.0604 \\
\hline & & & & PMY & 1.34 & 0.0051 & PMY & 1.73 & 0.0070 \\
\hline & $\mathrm{V}$ & & & & & & Group & 1.38 & \\
\hline \multirow{7}{*}{7 wk } & & & & & & & & & \\
\hline & NEFA & $2.48^{*}$ & & NEFA & $2.39 *$ & & NEFA & 2.7 & \\
\hline & BCS & $2.32^{*}$ & -0.0986 & BCS & $2.33^{*}$ & -0.0998 & BCS & 1.38 & -0.0702 \\
\hline & IGF & 0.30 & -0.0002 & IGF-I & 0.25 & -0.0002 & IGF-I & 1.32 & -0.0010 \\
\hline & & & & PMY & 0.33 & 0.0014 & PMY & 0.42 & 0.0019 \\
\hline & & & & & & & Group & 1.49 & \\
\hline & Variance & & 0.0491 & & Variance & 0.0495 & Variance & & 0.0478 \\
\hline
\end{tabular}

${ }^{1}$ For $t$ and $F$ values, $* P<0.05,{ }^{*} P<0.01,{ }^{* * *} P<0.001$

${ }^{2}$ Variance is the error variance component. 
Table 9. Traits affecting interval to first service in primiparous cows at 4 different time points in relation to calving

\begin{tabular}{|c|c|c|c|c|c|c|c|c|c|}
\hline \multirow[b]{2}{*}{$\begin{array}{l}\text { Time } \\
\text { point }\end{array}$} & \multicolumn{3}{|c|}{$\begin{array}{c}\text { Model } 1 \\
\text { Metabolites and hormones }\end{array}$} & \multicolumn{3}{|c|}{$\begin{array}{c}\text { Model } 2 \\
\text { C-LA and PMY }{ }^{1}\end{array}$} & \multicolumn{3}{|c|}{$\begin{array}{c}\text { Model } 3 \\
\text { PMY, C-LA, and dietary group }\end{array}$} \\
\hline & $\begin{array}{l}\text { Factors } \\
\text { fitted }\end{array}$ & $t^{2}$ & $\begin{array}{l}\text { Regression } \\
\text { coefficient }\end{array}$ & $\begin{array}{l}\text { Factors } \\
\text { fitted }\end{array}$ & $t$ & $\begin{array}{l}\text { Regression } \\
\text { coefficient }\end{array}$ & $\begin{array}{l}\text { Factors } \\
\text { fitted }\end{array}$ & $t$ or $F^{2}$ & $\begin{array}{l}\text { Regression } \\
\text { coefficient }\end{array}$ \\
\hline \multirow[t]{3}{*}{$-1 \mathrm{wk}$} & BCS & $3.76^{* * * *}$ & 0.0954 & & & & BCS & $2.35^{*}$ & 0.0655 \\
\hline & Urea & $3.32 * * *$ & 0.0255 & & & & Urea & 0.3 & 0.0030 \\
\hline & Variance ${ }^{3}$ & & 0.01 & & & & $\begin{array}{l}\text { Group } \\
\text { Variance }\end{array}$ & $3.66^{* * *}$ & 0.0111 \\
\hline \multirow[t]{6}{*}{$2 \mathrm{wk}$} & BCS & $2.53 *$ & 0.0594 & BCS & $2.67 * *$ & 0.0625 & BCS & 0.01 & $-0.0003^{4}$ \\
\hline & Urea & $2.48^{*}$ & 0.0 & Urea & $2.52 *$ & 0.0 & Urea & 1.12 & $-0.0122^{4}$ \\
\hline & & & & PMY & 1.39 & 0.0031 & PMY & 1.06 & 0.0023 \\
\hline & & & & C-LA & 0.25 & 0.0127 & C-LA & 1.11 & 0.0511 \\
\hline & & & & & & & Group & $6.08 * * *$ & \\
\hline & Variance & & 0.0189 & Variance & & 0.0180 & Variance & & 0.0141 \\
\hline \multirow[t]{6}{*}{$4 \mathrm{wk}$} & Urea & $3.93^{* * *}$ & 0 . & Ur & $4.62 * * *$ & 0 & Ure & 0.32 & 0. \\
\hline & BHBA & 0.44 & 0.0251 & BHBA & $2.53^{*}$ & 0.0909 & BHBA & 0.70 & 0.0243 \\
\hline & & & & PMY & 0.45 & 0.0010 & PMY & 0.77 & 0.0017 \\
\hline & & & & C-LA & 0.69 & 0.0361 & C-LA & 1.7 & 0.0820 \\
\hline & & & & & & & Grou & 5.56 & \\
\hline & Variance & & 0.0199 & Variance & & 0.0163 & Variance & & 0.0127 \\
\hline \multirow[t]{5}{*}{$7 \mathrm{wk}$} & Urea & $5.00 * * *$ & 0.0322 & Ure & $4.94 * * *$ & 0.0 & Ure & 0.25 & 7 \\
\hline & & & & PMY & 0.74 & & PMY & 0.49 & 0.0012 \\
\hline & & & & C-LA & 0.71 & 0.0389 & C-LA & 0.81 & 0.0426 \\
\hline & Variance & & 0186 & 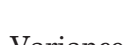 & & & Gro & 4.01 & $0 \Omega$ \\
\hline & Variance & & 0186 & Varıance & & .0177 & ce & & 0.0147 \\
\hline
\end{tabular}

${ }^{1} \mathrm{C}-\mathrm{LA}=$ commencement of luteal activity; $\mathrm{PMY}=$ peak milk yield.

${ }^{2}$ For $t$ and $F$ values, $* P<0.05, * * P<0.01, * * * P<0.001$.

${ }^{3}$ Variance is the error variance component.

${ }^{4}$ Note that when group was added to the model at $2 \mathrm{wk}$, the effect of BCS and urea changed from positive to slightly negative. This indicated that there were differences between herds in the direction of the relationship.

intervals to first service; Table 9). At the 2 later time points (4 and $7 \mathrm{wk}$ ), only the effect of urea remained significant $(P<0.001)$. Inclusion of PMY and C-LA in model 2 was not significant at any time, although these factors did consistently improve the fit of the model. As with the MP cows, inclusion of the dietary group in model 3 was significant $(P<0.001)$, and when this was included, the effect of urea was no longer significant. Because the regression coefficients for BCS and urea at 2 wk changed from positive to negative following the addition of dietary group, this implied that there were differences in the direction of this trend among groups.

Interval to Conception. Factors affecting the interval to conception in PP cows were similar to those important in the interval to first service (Table 10). In model 1 before calving, a significant positive relationship was detected for the interval to conception with BCS $(P<0.01)$ and urea $(P<0.05)$. After calving, the relationship with urea remained positive, whereas that with BCS became negative, indicating that BCS loss was an important consideration. Addition of both BHBA and IGF-I to the model improved the fit at $4 \mathrm{wk}$, with the positive relationships showing that greater concentrations at $4 \mathrm{wk}$ were associated with prolonged intervals to conception. In contrast to the MP cows, the influence of PMY in model 2 was not significant. Inclusion of C-LA was significant at both 2 and $7 \mathrm{wk}$ $(P<0.05)$. Addition of dietary group to model 3 was significant at both $2(P<0.05)$ and $4 \mathrm{wk}(P<0.001)$. Its addition removed the significance of urea at all time points.

The influence of C-LA and PMY on the calving to conception interval is summarized in Table 7. As with the MP cows, C-LA increased $(P<0.05)$ as the calving to conception interval increased. Although the trend was in the same direction for PMY, differences were much smaller than in MP cows (only $2 \mathrm{~kg} / \mathrm{d}$ between cows with the shortest and longest intervals).

\section{Relationship Between Fertility and Measured Values of BCS and Urea}

One aim of the present study was to evaluate the usefulness of tests available to dairy farmers and veterinarians to predict fertility outcomes. The results showed that BCS and urea were most likely to prove 
Table 10. Traits influencing interval to conception in primiparous cows at 4 different time points in relation to calving

\begin{tabular}{|c|c|c|c|c|c|c|c|c|c|}
\hline \multirow[b]{2}{*}{$\begin{array}{l}\text { Time } \\
\text { point }\end{array}$} & \multicolumn{3}{|c|}{$\begin{array}{l}\text { Model } 1 \\
\text { Metabolites and hormones }\end{array}$} & \multicolumn{3}{|c|}{$\begin{array}{c}\text { Model } 2 \\
\text { C-LA and PMY }\end{array}$} & \multicolumn{3}{|c|}{$\begin{array}{c}\text { Model } 3 \\
\text { PMY, C-LA, and dietary group }\end{array}$} \\
\hline & $\begin{array}{l}\text { Factors } \\
\text { fitted }\end{array}$ & $t^{2}$ & $\begin{array}{l}\text { Regression } \\
\text { coefficient }\end{array}$ & $\begin{array}{l}\text { Factors } \\
\text { fitted }\end{array}$ & $t$ & $\begin{array}{l}\text { Regression } \\
\text { coefficient }\end{array}$ & $\begin{array}{l}\text { Factors } \\
\text { fitted }\end{array}$ & $t$ or $F^{2}$ & $\begin{array}{l}\text { Regression } \\
\text { coefficient }\end{array}$ \\
\hline \multirow[t]{4}{*}{$-1 \mathrm{wk}$} & BCS & $2.73^{* *}$ & 0.1086 & & & & BCS & 1.66 & 0.0810 \\
\hline & Urea & $2.12^{*}$ & 0.0246 & & & & Urea & 0.20 & 0.0030 \\
\hline & & & & & & & Group & 1.39 & \\
\hline & Variance $^{3}$ & & 0.0292 & Variance & & & Variance & & 0.0279 \\
\hline \multirow[t]{5}{*}{$2 \mathrm{wk}$} & Urea & $2.97^{* *}$ & 0.0277 & Urea & $3.21 * *$ & 0.0306 & Urea & 1.05 & 0.0166 \\
\hline & & & & PMY & 1.08 & 0.0 & PMY & $2.53^{*}$ & 0.0035 \\
\hline & & & & C-LA & $2.34^{*}$ & 0.1536 & C-LA & 1.07 & 0.1655 \\
\hline & & & & & & & Grou & $2.56^{*}$ & \\
\hline & Variance & & 0.0311 & Variance & & 0.0297 & Variance & & 0.0271 \\
\hline \multirow[t]{9}{*}{$4 \mathrm{wk}$} & BHBA & $2.68^{* *}$ & 0.1818 & BHBA & 2.57 & 0.1 & BHBA & 1. & 0.1452 \\
\hline & IGF-I & $2.55^{*}$ & 0.0015 & IGF- & $2.62^{* *}$ & 0.001 & IGF-I & 3.1 & 0.0017 \\
\hline & BCSA & $2.11 *$ & -0.0739 & BCS & 1.92 & -0.0688 & $\mathrm{BCS}$ & $3.96^{* * *}$ & -0.1375 \\
\hline & Urea & 1.57 & 0.0194 & Urea & 1.53 & 0.0196 & Urea & 1.96 & $-0.0363^{4}$ \\
\hline & NEFA & $1.16^{*}$ & -0.0968 & NEFA & 1.28 & -0.1074 & NEFA & 0.81 & -0.0771 \\
\hline & & & & PMY & 0.73 & 0.0026 & PMY & 1.05 & 0.0036 \\
\hline & & & & C-LA & 0.97 & 0.0807 & C-LA & 1.11 & 0.0840 \\
\hline & & & & & & & Group & $4.58^{* * *}$ & \\
\hline & Variance & & 0.0295 & Variance & & 0.0296 & Variance & & 0.0229 \\
\hline \multirow[t]{6}{*}{$7 \mathrm{wk}$} & Urea & $2.79 * *$ & 0.0334 & Urea & $3.13^{* *}$ & 0.0392 & Urea & 1.04 & 0.0236 \\
\hline & BCS & 1.11 & -0.0423 & BCS & 0.74 & -0.0286 & BCS & 1.64 & -0.0704 \\
\hline & & & & PMY & 0.59 & 0.0021 & PMY & 0.96 & 0.0037 \\
\hline & & & & C-LA & $1.97 *$ & 0.1655 & C-LA & 1.64 & 0.1403 \\
\hline & & & & & & & Group & 1.79 & \\
\hline & Variance & & 0.0308 & Variance & & 0.0300 & Variance & & 0.0281 \\
\hline
\end{tabular}

${ }^{1} \mathrm{C}-\mathrm{LA}=$ commencement of luteal activity; PMY = peak milk yield.

${ }^{2}$ For $t$ and $F$ values, $* P<0.05$, $* * P<0.01$, $* * * P<0.001$

${ }^{3}$ Variance is the error variance component.

${ }^{4}$ Note that when group was added to the model at $4 \mathrm{wk}$, the effect of urea changed from positive to negative. This indicated that there were differences between herds in the direction of the relationship.

useful in this regard. A final analysis was therefore performed in which mean intervals to first service and conception were calculated for cows having high, medium, or low values for BCS and urea at 1 wk before calving and at $7 \mathrm{wk}$ postpartum (at the end of the voluntary waiting period; Table 11). Although MP cows having a lower BCS at 7 wk took 3 wk longer to conceive, this difference was not significant. Concentrations of urea were predictive of fertility in MP cows, but the relationship with fertility was reversed during the calving period, such that it was beneficial to have an increased prepartum concentration $(>7.5 \mathrm{mmol} / \mathrm{L})$ but a reduced concentration $(<4.5 \mathrm{mmol} / \mathrm{L})$ at 7 wk postpartum. In PP cows, BCS at both time points predicted the interval to first service, with cows having a poor BCS of $<2$ being inseminated earlier. However, there was no relationship between BCS at $7 \mathrm{wk}$ and the interval to conception in PP cows. Urea concentrations were again useful in predicting fertility, but in PP cows, the trend was for cows having concentrations $>7.5 \mathrm{mmol} / \mathrm{L}$ both before and after calving to have poorer fertility than those in which urea concentrations were lower.

\section{DISCUSSION}

Previous studies have examined relationships between metabolic status and fertility, but few have adopted the approach used here of systematically examining the relationships among each of a variety of metabolites and fertility outcomes at specific time points in relation to calving. In addition, the age of the cow has not always been considered, which may have masked some potentially significant relationships. Primiparous cows, which comprise about one-third of all cows in a typical UK herd, are still growing and are directing nutrients into growth as well as milk production. Generally, by the second lactation, growth is almost complete and milk production potential has increased considerably (Coffey et al., 2006). The metabolic status is therefore different at the start of the second and subsequent lactations. An initial comparison of the results from our study found that compared with MP cows, PP cows produced less milk and had greater IGFI and lower BHBA concentrations throughout the study period. Leptin concentrations also were greater before 
Table 11. Summary of BCS and urea responses at $1 \mathrm{wk}$ before and $7 \mathrm{wk}$ after calving in relation to the subsequent fertility of multiparous (MP) and primiparous (PP) cows ${ }^{1}$

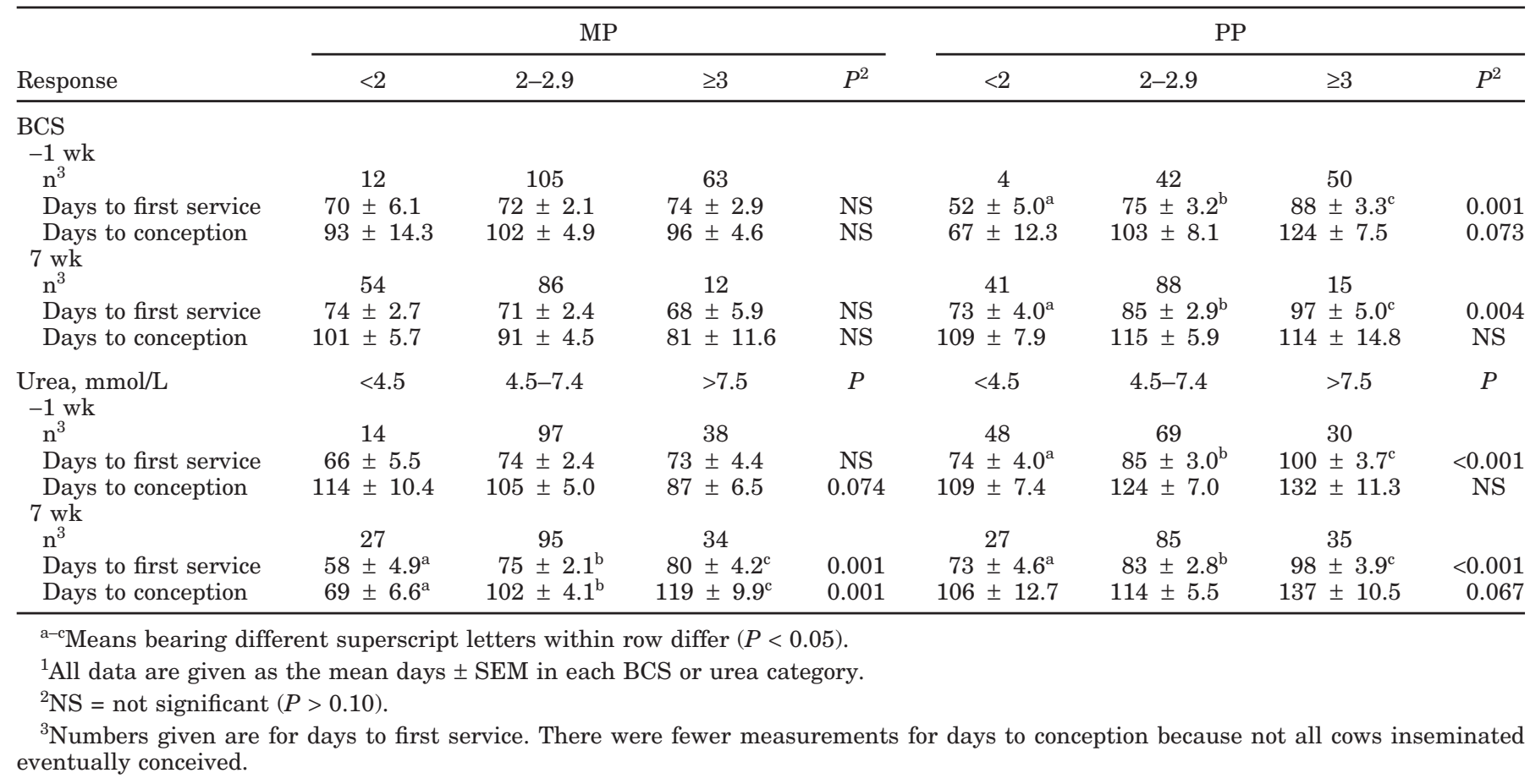

calving in the PP cows, and their NEFA peak occurred sooner after calving (Wathes et al., 2006). We show herein that the relationships among metabolic traits and fertility also differed among age groups. However, within each age group there were clearly changing patterns of metabolic status over time that were associated with a poorer fertility outcome.

Inclusion of the dietary group as a fixed factor in model 3 accounted for both management and feed differences among herds. Inclusion of dietary group played a significant role in predicting the interval to first service in both age groups, suggesting that this timing was, to some extent, influenced by management decisions as well as by diet. Despite this role of diet, inclusion of dietary group in predicting the calving to conception interval was not significant at any time point in MP cows and made little difference to the overall fit of the model. This indicates that individual cow factors related to either the amount of DM consumed or how it was utilized had a more important influence on the ability of cows to conceive than did either the actual diet or the timing of their first insemination. Disease factors such as retained fetal membranes and endometritis also were likely to be influential but were not considered here. In PP cows, inclusion of dietary group did, however, significantly influence conception intervals at 2 of the 4 time points considered. This could possibly reflect the fact that one of the numerically largest groups, comprising $23 \%$ of the population studied, had the highest protein:energy ratio, $19.2 \mathrm{~g}$ of CP/ $\mathrm{MJ}$, and the worst fertility, with an average calving to conception interval of $143 \mathrm{~d}$ and with $23 \%$ of cows failing to conceive. It also was notable that when dietary group was added to the models related to interval to conception, the urea concentration was no longer of significance in either MP or PP cows. This absence of a relationship between concentrations of urea and the interval to conception supports the view (discussed below) that urea was influenced by the diet. However, it should be noted that all herds in the study were fed diets that were intended to meet the protein and energy requirements of the cows. With the exception noted, the protein:energy ratios in all other cases were between 11.4 and $16.5 \mathrm{~g}$ of $\mathrm{CP} / \mathrm{MJ}$. Trials that use more extreme diets, in which energy requirements are not met, might produce different conclusions.

In MP cows, increased concentrations of leptin before and immediately after calving were a strong predictor of a delayed C-LA, and increased prepartum leptin was also associated with prolonged intervals to first service and to conception. In contrast, the prepartum leptin concentration was not related to any fertility outcome in PP cows. The significant relationship between leptin and the calving to conception interval was present only in the prepartum sample, suggesting that circulating leptin was unlikely to influence fertility by direct effects 
on follicular or luteal function. No relationship was detected between postcalving leptin concentrations and C-LA, although cows with irregular cycles had lesser circulating leptin (Reist et al., 2003; Mann et al., 2005). Leptin concentrations decrease at calving (Ingvartsen and Boisclair, 2001). The prepartum leptin concentration was correlated with BCS (Ehrhardt et al., 2000; Wathes et al., 2006), and may therefore be indicative of the amount of adipose tissue available for subsequent mobilization to support lactation. It is also possible that elevated prepartum leptin may reduce the appetite, and thus contribute to greater BCS loss via reduced DMI (Blache et al., 2000a).

Two traditional measures of energy balance in cows are NEFA and BHBA (Bauman and Currie, 1980). Concentrations of these 2 metabolites normally increase shortly after calving as lactation commences. The increase in NEFA is generally of short duration $(<5 \mathrm{wk})$, but our results showed that in both MP and PP cows having a prolonged C-LA, the NEFA peak remained high longer, with significant influences at 4 and $7 \mathrm{wk}$, respectively. In MP cows, a greater BHBA concentration immediately after calving ( $2 \mathrm{wk}$ ) was associated with prolonged intervals to C-LA, but otherwise, BHBA was not significant in any of the models. Reduced prepartum NEFA also increased the interval to conception in MP cows. A prepartum rise in NEFA suggested that cows were already in NEB at this time and were mobilizing lipids as an energy source (Duffield, 2000). In PP cows, a prolonged C-LA was associated with reduced BHBA concentrations before calving and greater BHBA after calving, coupled with reduced urea. This suggested that both a lack of tissue mobilization before calving and inadequate protein intake were important factors in those PP cows that later took longer to resume cyclicity. Elevated BHBA and NEFA concentrations may become influential on fertility only when they rise above a critical threshold. However, it is unlikely that this affected interpretation of the results. Particularly for NEFA, some cows with elevated concentrations $(>0.5 \mathrm{mmol} / \mathrm{L})$ conceived quite soon after calving, whereas others took longer despite their NEFA concentrations remaining low.

In MP cows, intervals to first service and to conception were influenced by reduced BCS at 4 and 7 wk. Pryce et al. (2001) similarly reported a negative correlation between BCS at $10 \mathrm{wk}$ and the interval to conception. In PP cows, however, greater BCS before calving followed by lower BCS at 4 and 7 wk predicted a prolonged interval to conception. Those PP cows with a BCS $\geq 3$ at 1 wk before calving took 3 wk longer to conceive than those calving with a BCS in the range of 2.0 to 2.9. This suggested that PP cows calving with higher body condition subsequently mobilized more tis- sue, with deleterious consequences on fertility. Using a multivariate analysis, Westwood et al. (2002) identified a significant influence of BW loss in the first $6 \mathrm{wk}$ of lactation on the calving to conception interval in MP cows. Ruegg et al. (1992) also reported prolonged intervals to conception in MP cows calving with a BCS $>3$.

The first trait after calving related to prolonged intervals to both first service and conception in MP cows was a reduced IGF-I concentration. During the early postpartum period, GH becomes uncoupled from IGFI production by the liver because of down-regulation of liver GH receptors (Lucy et al., 2001). However, by 7 wk the somatotropic axis has recovered, so that $\mathrm{GH}$ is again able to stimulate liver IGF-I synthesis (Butler et al., 2003). Previous studies have shown that cows with reduced postpartum concentrations of IGF-I took longer to resume cyclicity, because their first dominant follicle was less likely to ovulate (Beam and Butler, 1999; Pushpakumara et al., 2003). However, influence of IGF-I on fertility is not just through a delayed start to cyclicity. Indeed, the current data showed significant effects on intervals to first service and to conception, whereas the IGF-I concentration was not significant in the models related to C-LA. We also showed previously that MP cows that failed to conceive at all had lesser IGF-I concentrations, both before and after calving (Taylor et al., 2004). Reduced IGF-I around calving reflects energy balance status and may adversely influence conception through production of poorer quality oocytes (Snijders et al., 2000) or may have adverse influences on early embryo development by altering the oviduct and uterine environment (Robinson et al., 2000; Pushpakumara et al., 2002). This is supported by studies in which bST injection at the time of insemination improved conception rates in repeat-breeder cows (Morales-Roura et al., 2001). The lack of effect of reduced IGF-I concentration on fertility in PP cows is likely, because their circulating concentrations were nearly twice those measured in MP cows (Taylor et al., 2004), so reduced concentrations never occurred. Insulin is an important regulator of IGF-I synthesis, because hypoinsulinemia contributes to the postpartum down-regulation of the liver-specific variant of the GH receptor (GHR1A; Butler et al., 2003). Although insulin measurements were included in all the analyses, they did not significantly improve the fit of any of the models used to predict the interval to first service or to conception.

Inclusion of urea was significant in many of the models related to fertility, but the relationships differed between age groups and changed over time. In MP cows before calving, urea was negatively related to the interval to conception, whereas by the end of the voluntary waiting period ( $7 \mathrm{wk})$, an elevated urea concentration was the most deleterious factor influencing the calving 
to conception interval. Cows with blood urea concentrations $>7.5 \mathrm{mmol} / \mathrm{L}$ at that time needed $7 \mathrm{wk}$ longer to conceive than those with concentrations $<4.5 \mathrm{mmol} / \mathrm{L}$. In contrast, in PP cows, the intervals to first service and to conception were predicted by elevated urea at all time points studied, including those assessed before calving. These data are consistent with those of several previous studies reviewed by Moore and Varga (1996) showing that either reduced or elevated urea concentrations were associated with more days open. Butler (2001) found that cows exceeding a threshold of $19 \mathrm{mg}$ of BUN/dL (approximately $6.8 \mathrm{mmol} / \mathrm{L}$ ) had poorer fertility. Many factors contribute to the actual blood urea concentration measured in both late-pregnant and early-lactating ruminants. These include the degree of catabolism of AA stored in skeletal muscle to meet the requirements of the conceptus (prepartum), and mammary gland (postpartum) and dietary factors (Bell, 1995; Moore and Varga, 1996). Concentration of blood urea is influenced by both the ratio and concentration of RDP and RUP and the ratio of energy to protein in the diet. Circulating ammonia concentrations increase after degradation of RDP, particularly during energy deficit, and urea production by the liver also requires energy and may exacerbate the NEB. Impaired liver function, as commonly occurs after calving, also reduces the metabolic clearance of urea (O'Callaghan et al., 2001). Elevated blood urea also can be caused by a low rumen $\mathrm{pH}$, which inhibits the growth of microorganisms, whereas reduced voluntary DMI around calving, liver failure, or both may contribute to reduced urea (Moore and Varga, 1996).

It is still unclear how either of these extremes in urea concentration cause poor fertility. Butler (2001) suggested that the deleterious effect of elevated urea may be mediated through increased uterine $\mathrm{pH}$, which is then hostile to both gametes and embryos. An adverse effect of urea on oocytes was supported by Sinclair et al. (2000), who showed that in vitro blastocyst production was adversely affected when oocytes were derived from heifers fed a diet designed to generate high ammonia concentrations. Conversely, conception rates were similar when in vitro-produced embryos were transferred to heifers on elevated or reduced urea-generating diets (O'Callaghan et al., 2001). In a review, Laven et al. (1999) concluded that, although evidence exists for adverse effects on fertility of elevated circulating urea, cows were able to adapt to a high dietary nitrogen input over several days. An elevated urea concentration was thus mainly indicative of an imbalance between protein and energy supply, representing another measure of NEB. At the other end of the concentration range, previous studies reported that feeding diets having inadequate protein during late gestation was associated with weak calves, stillbirths, and more retained fetal membranes (Moore and Varga, 1996). All of these problems subsequently have an impact on fertility.

The C-LA did not influence the interval to first service but did affect the interval to conception. Twice as many (20.7\%) PP cows as MP cows (9.5\%) showed a delayed ovulation milk progesterone profile. This aspect of subfertility therefore had a greater impact on the calving to conception interval in PP cows. Both MP and PP cows that took longer than $150 \mathrm{~d}$ to conceive had prolonged CLA intervals. Previous studies have shown that fertility improves when ovulation occurs earlier, allowing time for more cycles to occur before insemination (Butler and Smith, 1989).

Addition of PMY to the models of fertility was influential in MP cows, because cows that required $>150$ $\mathrm{d}$ to conceive produced $13 \mathrm{~kg} / \mathrm{d}$ more milk than those conceiving in $<80 \mathrm{~d}$. It was notable, however, that the most significant influence of PMY was obtained at 2 wk, whereas PMY was not actually achieved until about 5 to $7 \mathrm{wk}$. This suggests that the underlying metabolic changes associated with early postpartum tissue mobilization to promote milk production were likely the cause of poor fertility, rather than the act of producing a large amount of milk once lactation had been fully established. In PP cows, which had not yet reached their full milk production potential, PMY (again at 2 wk) adversely affected C-LA, but no relationship was detected with the intervals to first service or conception. The significantly greater circulating concentrations of IGF-I measured in the PP cows may direct partitioning of nutrients into body tissue rather than milk, so yield may not be such an important factor in limiting fertility in the less mature cows (Wathes et al., 2006).

\section{CONCLUSIONS}

In MP cows, the sequence of metabolic and endocrine changes leading to longer calving to conception intervals was as follows: elevated leptin, reduced NEFA, and reduced urea prepartum; reduced IGF-I at $2 \mathrm{wk}$; elevated urea at $7 \mathrm{wk}$; and increased PMY. In contrast, longer calving to conception intervals in PP cows were associated with increased BCS and urea prepartum, with the urea staying high postpartum and with significant BCS loss by $7 \mathrm{wk}$. Measurements made before calving were equally as good at predicting fertility as those made at $7 \mathrm{wk}$ (end of the voluntary waiting period). These results indicate the importance of prepartum metabolic status for subsequent fertility, particularly in PP cows in which increased BCS at this time probably predisposed cows to a high rate of tissue mobilization. 


\section{ACKNOWLEDGMENTS}

The authors thank the farm staff who contributed to this study. We also are grateful to Sue Brotherstone (SAC, Edinburgh, UK) for helpful guidance with the use of ASREML. The work was funded by the UK Milk Development Council (Cirencester, Gloucestershire, UK) and Defra (London, UK).

\section{REFERENCES}

Bauman, D. E., and W. B. Currie. 1980. Partitioning of nutrients during pregnancy and lactation: A review of mechanisms involving homeostasis and homeorhesis. J. Dairy Sci. 63:1514-1529.

Beam, S. W., and W. R. Butler. 1999. Effects of energy balance on follicular development and first ovulation in postpartum dairy cows. J. Reprod. Fertil. Suppl. 54:411-424.

Beever, D. E., A. Hattan, C. K. Reynolds, and S. B. Cammell. 2001. Nutrient supply to high-yielding dairy cows. Pages 119-131 in Fertility in the High-Producing Dairy Cow. Occasional Publication No. 26. Br. Soc. Anim. Sci., Edinburgh, UK.

Bell, A. W. 1995. Regulation of organic nutrient metabolism during transition from late pregnancy to early lactation. J. Anim. Sci. 73:2804-2819.

Blache, D., P. Celi, M. A. Blackberry, R. A. Dynes, and G. B. Martin. 2000 a. Decrease in voluntary feed intake and pulsatile luteinizing hormone secretion after intracerebroventricular infusion of recombinant bovine leptin in mature male sheep. Reprod. Fertil. Dev. 12:373-381.

Blache, D., R. L. Tellam, L. M. Chagas, M. A. Blackberry, P. E. Vercoe, and G. B. Martin. 2000b. Level of nutrition affects leptin concentrations in plasma and cerebrospinal fluid in sheep. J. Endocrinol. 165:625-637.

Britt, J. H. 1994. Follicular development and fertility: Potential impacts of negative energy balance. Pages 103-112 in Proc. Natl. Reprod. Symp., Pittsburgh, PA. Texas Agric. Ext. Serv., College Station, TX.

Bulman, D. C., and G. E. Lamming. 1978. Milk progesterone levels in relation to conception, repeat breeding and factors influencing acyclicity in dairy cows. J. Reprod. Fertil. 54:447-458.

Butler, W. R. 2001. Nutritional effects on resumption of ovarian cyclicity and conception rate in postpartum dairy cows. Pages 133-145 in Fertility in the High-Producing Dairy Cow. Occasional Publication No. 26. Br. Soc. Anim. Sci., Edinburgh, UK.

Butler, S. T., A. L. Marr, S. H. Pelton, R. P. Radcliff, M. C. Lucy, and W. R. Butler. 2003. Insulin restores GH responsiveness during lactation-induced negative energy balance in dairy cattle: Effects on expression of IGF-I and GH receptor 1A. J. Endocrinol. 176:205-217.

Butler, W. R., and R. D. Smith. 1989. Interrelationships between energy balance and postpartum reproductive function in dairy cattle. J. Dairy Sci. 72:767-783.

Coffey, M. P., J. Hickey, and S. Brotherstone. 2006. Genetic aspects of growth of Holstein-Friesian dairy cows from birth to maturity. J. Dairy Sci. 89:322-329.

Duffield, T. 2000. Subclinical ketosis in lactating dairy cattle. Metab. Disord. Rumin. 16:231-253.

Ehrhardt, R. A., R. M. Slepetis, J. Siegal-Willott, M. E. Van Amburgh, A. W. Bell, and Y. R. Boisclair. 2000. Development of a specific radioimmunoassay to measure physiological changes of circulating leptin in cattle and sheep. J. Endocrinol. 166:519-528.

Enright, W. J., L. T. Chapin, W. M. Moseley, S. A. Zinn, M. B. Kamdar, L. F. Krabill, and H. A. Tucker. 1989. Effects of infusions of various doses of bovine growth hormone-releasing factor on blood hormones and metabolites in lactating Holstein cows. J. Endocrinol. 122:671-679.

Ferguson, J. D., and W. Chalupa. 1989. Impact of protein nutrition on reproduction in dairy cows. J. Dairy Sci. 72:746-766.
Gilmour, A. R., B. J. Gogel, B. R. Cullis, S. J. Welham, and R. Thompson. 2003. ASREML User Guide. Release 1.0. VSN International Ltd., Hemel Hempstead, UK.

Ingvartsen, K. L., and Y. R. Boisclair. 2001. Leptin and the regulation of food intake, energy homeostasis and immunity with special focus on periparturient ruminants. Domest. Anim. Endocrinol. $21: 215-250$

Jordan, E. R., and L. V. Swanson. 1979. Effects of crude protein on reproductive efficiency, serum total protein, and albumin in the high producing dairy cow. J. Dairy Sci. 62:58-63.

Laven, R. A., and S. B. Drew. 1999. Dietary protein and the reproductive performance of cows. Vet. Rec. 145:687-695.

Lucy, M. C., H. Jiang, and Y. Kobayashi. 2001. Changes in the somatotrophic axis associated with the initiation of lactation. J. Dairy Sci. 84(E Suppl.):E113-E119.

Mann, G. E., S. J. Mann, D. Blache, and R. Webb. 2005. Metabolic variables and plasma leptin concentrations in dairy cows exhibiting reproductive cycle abnormalities identified through milk progesterone monitoring during the post partum period. Anim. Reprod. Sci. 88:191-202.

Meikle, A., M. Kulcsar, Y. Chilliard, H. Febel, C. Delavaud, D. Cavestany, and P. Chilibroste. 2004. Effects of parity and body condition at parturition on endocrine and reproductive parameters of the cow. Reproduction 127:727-737.

Moore, D. A., and G. Varga. 1996. BUN and MUN: Urea nitrogen testing in dairy cattle. Compendium 18:712-720.

Morales-Roura, J. S., L. Zarco, J. Hernandez-Ceron, and G. Rodríguez. 2001. Effect of short-term treatment with bovine somatotropin at estrus on conception rate and luteal function of repeat-breeding dairy cows. Theriogenology 55:1831-1841.

O'Callaghan, D., J. M. Lozano, J. Fahey, V. Gath, S. Snijders, and M. P. Boland. 2001. Relationships between nutrition and fertility in cattle. Pages 147-160 in Fertility in the High-Producing Dairy Cow. Occasional Publication No. 26. Br. Soc. Anim. Sci., Edinburgh, UK.

Opsomer, G., M. Coryn, H. Deluyker, and A. de Kruif. 1998. An analysis of ovarian dysfunction in high yielding dairy cows after calving based on progesterone profiles. Reprod. Domest. Anim. 33:193-204.

Pryce, J. E., M. P. Coffey, and G. Simm. 2001. The relationship between body condition score and reproductive performance. J. Dairy Sci. 84:1508-1515.

Pushpakumara, P. G. A., N. H. Gardner, C. K. Reynolds, D. E. Beever, and D. C. Wathes. 2003. Relationships between transition diet, metabolic parameters and fertility in lactating cows. Theriogenology 60:1165-1185.

Pushpakumara, P. G. A., R. S. Robinson, K. J. Demmers, G. E. Mann, K. D. Sinclair, R. Webb, and D. C. Wathes. 2002. Expression of the insulin-like growth factor (IGF) system in the bovine oviduct at oestrus and during early pregnancy. Reproduction 123:859868.

Reist, M., D. K. Erdin, D. von Euw, K. M. Tschumperlin, H. Leuenberger, H. M. Hammon, C. Morel, C. Philipona, Y. Zbinden, N. Kunzi, and J. W. Blum. 2003. Postpartum reproductive function: Association with energy, metabolic and endocrine status in high yielding dairy cows. Theriogenology 59:1707-1723.

Robinson, R. S., G. E. Mann, T. S. Gadd, G. E. Lamming, and D. C. Wathes. 2000. The expression of the IGF system in the bovine uterus throughout the oestrous cycle and early pregnancy. J. Endocrinol. 165:231-243.

Royal, M., G. E. Mann, and A. P. F. Flint. 2000. Strategies for reversing the trend towards subfertility in dairy cattle. Vet. J. 160:53-60.

Ruegg, P. L., W. J. Goodger, C. A. Holmberg, L. D. Weaver, and E. M. Huffman. 1992. Relation among body condition score, milk production, and serum urea nitrogen and cholesterol concentrations in high-producing Holstein dairy cows in early lactation. Am. J. Vet. Res. 53:5-9.

Sinclair, K. D., M. Kuran, F. E. Gebbie, R. Webb, and T. G. McEvoy. 2000. Nitrogen metabolism and cattle fertility: II. Development of oocytes recovered from heifers offered diets differing in their rate of nitrogen release in the rumen. J. Anim. Sci. 78:2670-2680. 
Snijders, S. E. M., P. Dillon, D. O'Callaghan, and M. P. Boland. 2000. Effect of genetic merit, milk yield, body condition and lactation number on in vitro oocyte development in dairy cows. Theriogenology 53:981-989.

Spicer, L. J. 2001. Leptin, a possible metabolic signal affecting reproduction. Domest. Anim. Endocrinol. 21:251-270.

Taylor, V. J., D. E. Beever, and D. C. Wathes. 2003. Physiological adaptations to milk production that affect fertility in high yielding dairy cows. Pages 37-71 in Dairying: Using Science to Meet Consumers' Needs. Occasional Publication No. 29. Br. Soc. Anim. Sci., Nottingham University Press, Nottingham, UK.

Taylor, V. J., Z. Cheng, P. G. A. Pushpakumara, D. E. Beever, and D. C. Wathes. 2004. Relationships between the plasma concentra- tions of insulin-like growth factor-I in dairy cows and their fertility and milk yield. Vet. Rec. 155:583-588.

Wathes, D. C., Z. Cheng, N. Bourne, V. J. Taylor, M. P. Coffey, and S. Brotherstone. 2006. Differences between primiparous and multiparous dairy cows in the inter-relationships between metabolic traits, milk yield and body condition score in the periparturient period. Domest. Anim. Endocrinol. doi:10.1016/j.domaniend. 2006.05.004

Webster, J. 1987. Understanding the Dairy Cow. BPS Professional Books, Oxford, UK.

Westwood, C. T., I. J. Lean, and J. K. Garvin. 2002. Factors influencing fertility of Holstein dairy cows: A multivariate analysis. J. Dairy Sci. 85:3225-3237. 